\title{
Do Firms Use Derivatives to Reduce their Dependence on External Capital Markets?
}

\author{
TIM R. ADAM ${ }^{\star}$ \\ Hong Kong University of Science \& Technology, Department of Finance, Clear Water Bay, \\ Kowloon, Hong Kong. E-mail: adam@ust.hk.
}

\begin{abstract}
This study investigates if the use of derivatives by corporations is likely to affect their financing strategies. I find a strong positive relation between the minimum revenue guaranteed by hedging and investment expenditures. This result implies that hedging increases the likelihood that investments can be financed internally. I also find that firms tend to finance their investment expenditures externally rather than internally. If external capital is more costly than internal capital it would clearly be in a firm's interest to reduce its dependence on external capital. Consistent with this result, I find that the median firm that does not hedge finances $100 \%$ of its investment expenditures externally, while the median firm that hedges finances only $86 \%$ of investments externally.
\end{abstract}

Key words: Financial risk management, hedging, investments, financing policy, financial constraints, gold mining industry.

\section{JEL classification codes: G32}

\section{Introduction}

Froot, Scharfstein and Stein (1993) show that firms may have an incentive to hedge if external capital is costly. In such case, firms use derivatives to increase the correlation between internal funds and their investments in order to reduce their dependence on external capital. The purpose of this study is to test if firms indeed use derivatives for the purpose of reducing their dependence on external capital markets. ${ }^{1}$

\footnotetext{
^ I am grateful to Sudipto Dasgupta, Jin Duan, Joseph Fan, Vidhan Goyal, Peter Tufano, Steven Wei, and an anonymous referee for many valuable suggestions. I would also like to thank George Allayannis, Ken Eades, Wake Epps and Robert King for their helpful comments on earlier versions of this paper. Finally, I thank seminar participants at Northwestern University, the University of Virginia, the 1999 Derivatives Securities conference, and at the 1999 FMA annual meeting for their comments and discussions. Any remaining errors are my own. Funding was provided by the HKUST Research Grants Committee under project no. DAG97/98.BM24.

1 This objective is interesting from a financial market development perspective also. If firms are able to use derivatives to reduce their dependence on external capital markets, then this would indicate that a well-developed derivatives market can overcome some of the constraints imposed by a less-developed capital market.
} 
There are several papers that have tested the empirical relevance of Froot, Scharfstein and Stein's (1993) theory. The earliest papers have focused on a firm's decision to use derivatives, based on the notion that a firm is more likely to hedge if the cost differential between internal and external capital is large. ${ }^{2}$ The empirical results show that the likelihood to use derivatives increases among larger firms and among firms with high R\&D expenditures. A high R\&D budget could indicate that external capital is relatively costly due to information asymmetries and the potential for asset substitution, but firm size should be negatively correlated with the cost differential between internal and external capital. Thus, the empirical results are ambiguous with respect to Froot, Scharfstein and Stein's (1993) financial constraints hypothesis.

A second line of research analyzes the extent of hedging. ${ }^{3}$ It is not clear, however, why financial constraints should affect the extent of hedging. In the absence of any costs of hedging, firms should fully hedge, independent of the magnitude of their financial constraints. In the presence of costs associated with hedging, firms should still fully hedge as long as the marginal benefit of hedging outweighs the costs. Thus, for an interior solution of the hedge ratio to exist, the cost of hedging must be a convex function of the extent of hedging. Only in this case would a change in the marginal benefit of hedging, e.g., a change in the magnitude of financial constraints, affect the extent of hedging. This is a strong requirement, and the only example that Froot et al. (1993) advanced is the existence of a natural hedge in which cash inflows and outflows are positively correlated. Since hedging would destroy this natural hedge, the optimal hedge ratio is less than one. In light of this argument, it is perhaps not surprising that the empirical studies explaining the extent of hedging have provided largely inconsistent results with respect to the financial constraints hypothesis. Some authors, e.g., Haushalter (2000), find evidence that financial constraints matter, while others, e.g., Tufano (1996), find the opposite.

Finally, Allayannis and Mozumdar (2000) analyze the effect of hedging on a firm's investment/cash flow sensitivity. Following Fazzari et al. (1998), they interpret a positive correlation between investment expenditures and internal cash flow as an indication of financial constraints, although Kaplan and Zingales (1997, 2000) criticize this interpretation on both theoretical and empirical grounds. Allayannis and Mozumdar (2000) show that firms that use derivatives display a lower investment/cash flow sensitivity than firms that do not use derivatives. This result is consistent with the hypothesis that hedging reduces financial constraints and thus lends support to Froot, Scharfstein and Stein's (1993) theory, but it does not address the broader question of whether hedging affects financing strategies.

Although the above mentioned empirical papers have provided many valuable insights about corporate risk management, they suffer from two methodological

\footnotetext{
2 See Nance et al. (1993), Dolde (1996), Mian (1996), and Géczy et al. (1997).

3 See Tufano (1996), Haushalter (2000), Allayannis and Ofek (2001), and Graham and Rogers (2002).
} 
limitations with respect to testing the financial constraints hypothesis. The first problem lies in identifying financially constrained firms. In the past, researchers have relied on proxy variables such as firm size, debt and liquidity ratios, marketto-book ratios, dividend policies, existence of a public debt rating, investment/cash flow sensitivities, etc. to measure the existence or the magnitude of financial constraints. Whether or not these proxy variables are successful in picking out financially constrained firms is highly controversial. ${ }^{4}$ Second, researchers who study the effects of risk management typically rely on a control group that represents how derivatives users would have behaved had they not used derivatives. If the decision to hedge were random, this approach would be valid and differences between hedgers and non-hedgers could be attributed to the use of derivatives. However, previous studies have shown that the decision to hedge is not random but rather a deliberate choice. Of course, there are econometric models that can control for the implied selection bias. Since to date we have only a limited understanding of this choice, it is unlikely that we can eliminate the selection bias completely, indicating that alternative test procedures are warranted.

To avoid these limitations, this study pursues a different method to answer the question, "Do firms use derivatives to reduce their dependence on external capital markets?" Instead of analyzing differences in financing strategies between hedgers and non-hedgers, this study determines if firms hedge their future investment expenditures. More concretely, this study examines if hedging increases the likelihood that future investments can be financed internally. ${ }^{5}$ In addition, I investigate how firms finance their investment expenditures. If it can be shown that firms hedge their future investment expenditures and that the marginal investment is financed externally, then this would constitute indirect evidence that firms hedge to reduce their dependence on external capital markets. The advantages of this approach are that it is not necessary to distinguish between financially constrained and unconstrained firms and that the group of non-hedgers need not be used as a control group. The disadvantage of this approach is that it provides only indirect evidence.

The sample for the econometric analysis is the North American gold mining industry. This sample choice has several advantages. First, financial constraints appear to be an important concern in the mining industry. Second, the similarity in risk exposures among gold mining firms implies that differences in hedging strategies are not merely reflections of differences in risk exposures but more likely reflections of differences in firm-specific factors such as financial constraints. Third, the detailed derivatives disclosures and similar accounting treatments of

\footnotetext{
${ }^{4}$ Kaplan and Zingales (1997) discuss why the relation between financial constraints and proxy variables is often ambiguous, even on theoretical grounds.

5 Froot et al. (1993) theory is, to my knowledge, the only theory of corporate risk management that directly associates future investment expenditures with hedging.
} 
derivatives transactions among gold mining firms make the above mentioned test method feasible. ${ }^{6}$

Consistent with previous studies, I find that larger and more mature firms are more likely to use derivatives than are smaller and less mature firms. The significance of the risk exposure is a further important determinant of the decision to hedge. Less diversified firms are more likely to hedge, which is consistent with the findings of Allayannis and Ofek (2001). More importantly, I find a strong and robust relation between the minimum revenue guaranteed by hedging and investment expenditures, suggesting that firms hedge their future investment expenditures, as predicted by Froot et al. (1993). In addition, I find that investment expenditures are a major determinant of the amount of capital that firms raise externally. Finally, I find that the median firm that does not hedge finances $100 \%$ of its investment expenditures externally, while the median firm that hedges finances only $86 \%$ of its investment expenditures externally. These results are consistent with the hypothesis that firms hedge to reduce their dependence on external capital markets.

The results are also consistent with Minton and Schrand (1999) who show that cash flow volatility reduces investment spending. Since accessing external capital markets is costly (see Myers and Majluf (1984)) firms do not raise external funds to make up for all their cash shortfalls but they also cut investments. The appropriate response to this underinvestment problem is not necessarily to reduce volatility per se but to reduce the negative impact of volatility on investment. By hedging investments and hence reducing their dependence on external capital markets, firms seem to be following this rationale.

The remainder of this paper is organized as follows. Section 2 develops testable hypotheses. Section 3 provides some background information about the gold mining industry. Section 4 describes the data and the construction of variables. Section 5 presents the econometric results. Finally, Section 6 concludes the paper.

\section{Hypotheses Development}

Froot, Scharfstein and Stein (1993) showed that firms have an incentive to hedge if external capital is more costly than internal capital. The purpose of hedging in this case is to align cash inflows with cash outflows to avoid the use of external financing. Hedging in this way generates additional cash inflows in those states of the world in which a firm experiences a cash shortfall. For example, if a firm is long in one asset and faces certain expenditures in the future, then the risk management objective can be achieved by purchasing put options (insurance) or by going short in forwards. The firm's future cash inflow would then become certain up to the hedged amount, ensuring that future expenditures can be financed internally. Pegasus Gold, a North American gold producer, seems to have adopted such a hedging strategy. In its 1997 annual report, management writes,

\footnotetext{
${ }^{6}$ See Section 3 for more details.
} 
The company entered into forward sales contracts to hedge the price risk associated with its gold sales and to assure itself of a fixed future income stream over the lives of its operating mines.

Froot et al. (1993) theory would predict that this fixed future income stream is positively related to the firm's expected future investment expenditures. Hedging in this way would imply that future investments can be financed internally independent of future gold prices. To test this proposition, I estimate the following regression model:

$$
F F I S=\alpha+\beta I+\gamma \text { Controls }+\varepsilon
$$

where FFIS denotes a firm's fixed future income stream and $I$ denotes the expected investment expenditures over the next year. ${ }^{7}$ A firm's fixed future income stream may not only be a function of its future expected investment expenditures, but also a function of the availability of other internal and external financing sources. For example, if a firm keeps a high cash balance, then it does not need to hedge as much. Therefore, appropriate control variables are added to the above regression.

The next step is to determine how investments are generally financed. If firms hedge their future investment expenditures and such investment expenditures are generally financed externally, then this would represent indirect evidence that firms reduce their dependence on external capital. ${ }^{8}$ If investment expenditures were generally financed internally, however, then hedging would not change the mix between internal and external financing because hedging cash flows are themselves a form of internal financing.

To test if investment expenditures are an important determinant of the amount of external financing raised, I estimate the following regression model:

$$
F I N C F=\alpha+\beta I+\gamma \text { Controls }+\varepsilon,
$$

where FINCF stands for a firm's financing net cash flow, i.e., the net amount of external capital raised. The coefficient $\beta$ measures how much external capital firms raise on average to finance one dollar's worth of investments. Since the amount of external capital raised should also be a function of the amount of internal funds available as well as the financial condition of a firm, appropriate control variables are added.

Finally, to facilitate the comparison of this study with previous research on risk management, I analyze the determinants of the decision and the extent of hedging. Since firms that are more financially constrained have a greater incentive to hedge, I expect the decision to hedge to be positively related to the magnitude of financial constraints. However, as explained in the introduction, it is not clear why the extent

\footnotetext{
7 Both variables will be scaled by firm size to eliminate heteroscedasticity due to size effects.

8 This statement assumes that external capital is more costly than internal capital, giving firms an incentive to rely on external capital only after all internal sources have been exhausted.
} 
of hedging should be related to the magnitude of financial constraints. I therefore expect there to be no or only a weak relationship between them.

\section{The Sample}

In order to calculate a firm's fixed future income stream, one must have detailed knowledge about the nature of a firm's risk exposure and its derivatives positions. The gold mining industry is, to my knowledge, the only industry in which risk exposures are sufficiently simple and in which derivatives disclosures are sufficiently broad such that the fixed future income stream can be calculated for a large number of firms. Moreover, the gold mining industry is an almost ideal candidate for analyzing what effects financial constraints have on hedging strategies. First, the industry focus implies that the sample firms share similar risk exposures. Thus, differences in the observed hedging strategies should not be a mere reflection of differences in exposures, but are more likely a result of differences in certain firm-specific characteristics such as financial constraints. Second, the accounting treatment of derivatives cash flows is the same across firms in the mining industry. This allows me to infer firms' cash flows with and without the effect of hedging, which is important for the construction of the control variables. ${ }^{9}$ Third, financial constraints appear to be a significant concern in the gold mining industry. Relatively few firms rely on debt and the firms that do tend to have poor credit ratings. The average $\mathrm{S} \& \mathrm{P}$ senior debt rating for these firms is $\mathrm{BB}$, which is below investment grade. The causes for this may lie in information asymmetries and the concentration of most firms on only gold mining activities. Information asymmetries exist with respect to a mining firm's major asset: the quality and quantity of the gold deposit in the ground. Outsiders can verify drill results only under great cost. These information asymmetries cause debt capital to be relatively costly. In addition, mining for gold is a high cost/high risk business. The major financial risk exposure is the future spot price of gold, which is determined by world demand and supply and hence not under the control of an individual firm. The gold price exposure is aggravated by limited operational flexibility. For example, unit production costs are mainly determined by geological factors of the deposit, giving management little flexibility in adjusting costs. In addition, firms in the gold mining industry tend to be small and undiversified. Most firms focus exclusively on the extraction of gold, which further increases banks' reluctance to extend credit to them. ${ }^{10}$ In times of depressed gold prices, especially since 1998 ,

\footnotetext{
${ }^{9}$ For a broader set of firms, it is often impossible to precisely infer hedging cash flows (see Allayannis and Mozumdar (2000)).

10 "While senior companies could arrange financing through the issuance of bonds, debentures, notes or preferred shares, junior and medium size companies are quite restricted in their ability to issue corporate IOUs." (F.H. Khan, Managing Director at Canadian Bond Rating Service (CBRS Inc.) in "Establishing Credit Ratings for Mining Companies")
} 
even equity capital can become prohibitively expensive. ${ }^{11}$ Hence, it appears that gold mining firms could ex ante gain significantly from financial risk management that reduces their dependence on external capital. Finally, the use of derivatives is widespread in the gold mining industry. By 1997, $70 \%$ of all gold mining firms had implemented risk management programs. ${ }^{12}$ This is about twice the average of non-financial firms in the US.

There are four other papers that have investigated risk management practices in the gold mining industry. Tufano (1996) tests several theories of corporate hedging. He assumes that firms hedge their future gold production and finds evidence mostly in support of theories of managerial risk-aversion. My analysis differs in two important aspects from that of Tufano's. First, I focus on the fixed future income stream guaranteed by hedging, while Tufano calculates the delta of the hedge portfolio. Second, I test whether firms hedge sales/production, cash flows, or investment expenditures, while Tufano implicitly assumes that firms hedge their future gold production. These differences are significant because if a firm hedges in order to alleviate the effects of its financial constraints, then the hedging portfolio must ensure that internal funds are sufficient to finance the firm's investments. The question then becomes how much of the future gold production must be sold short to guarantee that $x$ dollars are available for investments in the next period. Whether this entails hedging, say, $20 \%$ or $40 \%$ of production is not a function of financial constraints, but a function of the size of the firm's investment program. Therefore, one should focus on the fraction of investment that can be financed internally, rather than the fraction of production that has been hedged when evaluating the effects of financial constraints on hedging strategies.

Brown et al. (2001) examine the time-series characteristics of hedge ratios in the gold mining industry. They find that little of the variation in hedge ratios can be explained by traditional risk management theories. Furthermore, the authors find that some gold producers appear to have superior forecasting ability because an increase/decrease in their hedge ratios is correlated with a fall/rise in gold prices during the following one or two quarters. Two further papers examine the effects of risk management. Tufano (1998) studies gold price exposures for a cross-section of firms and finds that hedging has only a marginal effect on a firm's stock price sensitivity to gold prices. Petersen and Thiagarajan (2000) evaluate the hedging strategies of Barrick Gold and Homestake Mining, two major gold producers, and show that differences in operating cost structures could have led Barrick Gold to use financial hedges while they led Homestake Mining to use operational hedges.

\footnotetext{
11 "This [decline in gold prices] has limited the cash flow of many gold mining companies worldwide and restricted the access to capital through either the equity or debt markets." (TVX Gold Inc., 1998 annual report, p. 27).

12 See "Gold and Silver Hedge Outlook," Scotia McLeod Equity Research, 4th quarter, 1997.
} 


\section{Data Sources and Construction of Variables}

Annual data on derivatives positions in the North American gold mining industry are provided by the 'Gold \& Silver Hedge Outlook', a survey conducted by the Canadian financial analyst, Ted Reeve, between 1989 and 1999, and published by Scotia Capital. The survey provides information on the type of derivative instruments used, the size and direction of the positions taken, the delivery prices, and the maturity of each instrument for a total of 111 companies. These companies represent almost the entire North American gold mining industry. Companies that are not included in the survey tend to be small and privately held firms. Table I provides an example of the raw data. To ensure data accuracy, the survey data are compared with the derivatives disclosures in the financial footnotes of the firms' annual reports and 10-K forms.

Most financial data are obtained from the active, Canadian, and research tapes of the Compustat database. Financial data for firms included in the survey but not covered by Compustat are collected by hand from the firms' annual reports and $10-\mathrm{K}$ forms. Operational data, such as production and reserve statistics, cash costs, etc., are also collected by hand from the firms' annual reports and 10-K forms. Ownership information is obtained from proxy statements and management information circulars. Financial market data, such as gold spot and futures prices, interest and exchange rates, etc., are obtained from Datastream.

\subsection{DEFINITION OF VARIABLES}

The main variables used in this study are a firm's fixed future income stream, its expected future investment expenditures, and measures of the availability of internal and external capital. In addition, I include a measure of the extent of risk management following Froot et al. (1993) model and variables that have been used in previous studies to proxy for financial constraints. The construction of most variables is standard and therefore only summarized in Table II.

Given that gold producers have an inherent long exposure in gold, the fixed future income stream equals the number of ounces of gold hedged (using forwards, spot-deferred contracts, ${ }^{13}$ gold loans ${ }^{14}$ and put options) multiplied by the respective delivery prices. For example, suppose a firm expects to produce 200,000 ounces of gold and enters into forward agreements to deliver 100,000 ounces at a forward price of $\$ 330$ per ounce. Assuming the firm produces at least 100,000 ounces, it will receive a certain cash inflow of $\$ 33$ million $(\$ 330 \times 100,000)$ at the maturity

\footnotetext{
13 A spot-deferred contract is like a forward contract except that delivery can be deferred for several years at the discretion of the deliverer. If delivery is deferred, the new delivery price is set to equal the current forward price plus the future value of the current gain/loss on the contract. The option to defer delivery therefore amounts only to a guarantee that the hedger can defer any loss on the spot-deferred contract until the final maturity of the contract.

14 From the perspective of the issuer, the cash flows of a gold loan are identical to the cash flows from issuing regular debt and selling gold in the forward market.
} 

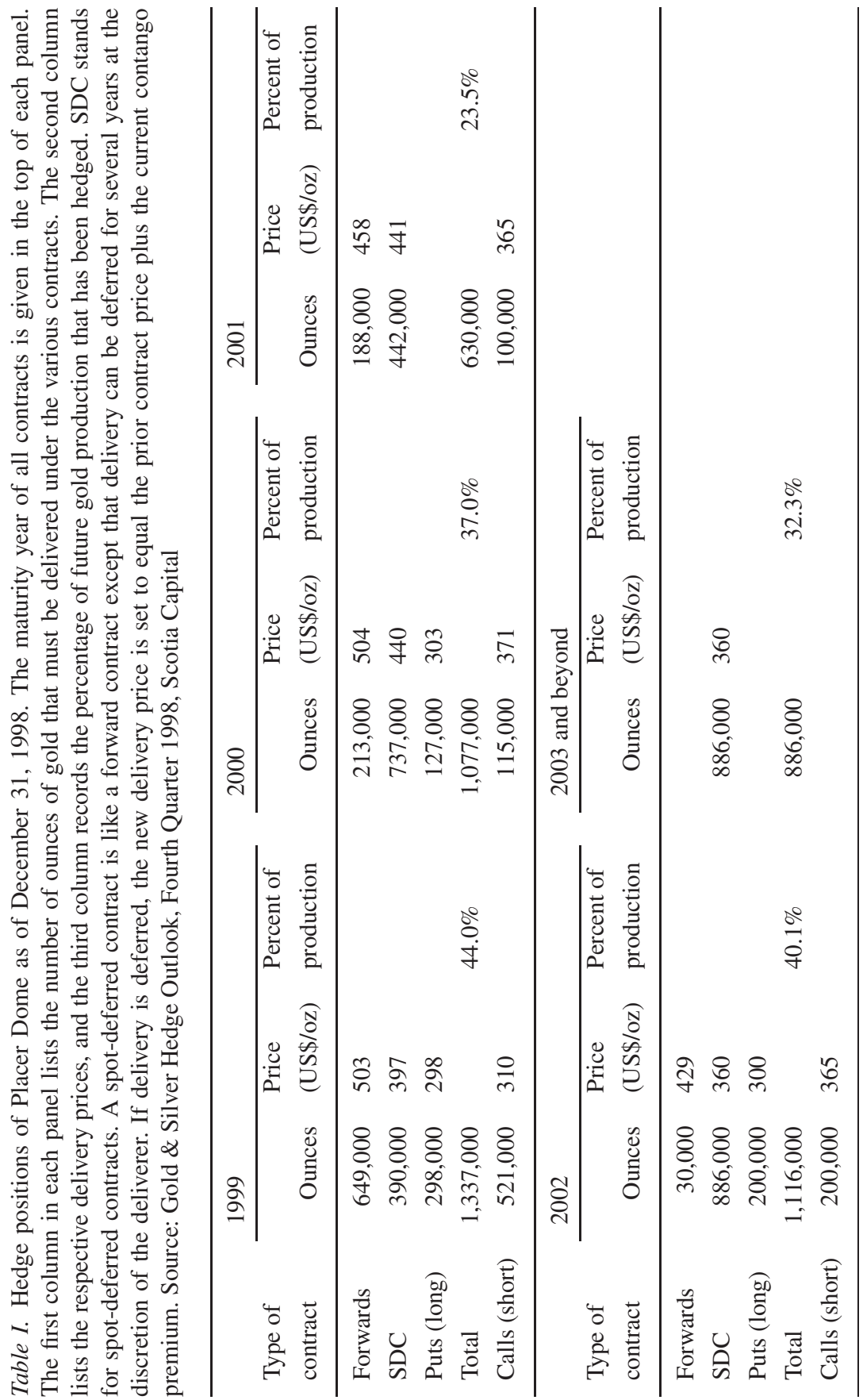
Table II. Description and construction of variables

\begin{tabular}{|c|c|c|}
\hline Variable name & Construction & Data sources \\
\hline \multicolumn{3}{|c|}{ Hedging variables } \\
\hline $\begin{array}{l}\text { Fixed future } \\
\text { income stream }\end{array}$ & $\begin{array}{l}\text { Cash inflow during period } t+1 \text { that is certain due to } \\
\text { hedging, in } \$ \text { Mill. The fixed future income stream is } \\
\text { defined by the product of the number of ounces of gold } \\
\text { hedged (using forwards, spot-deferred contracts, gold } \\
\text { loans and put options) and the respective delivery prices. } \\
\text { Only derivatives positions with a maximum of one year } \\
\text { to maturity are considered. }\end{array}$ & $\begin{array}{l}\text { Gold \& Silver } \\
\text { Hedge Survey } \\
(1989-1999)\end{array}$ \\
\hline $\begin{array}{l}\text { Hedging net } \\
\text { cash flow }\end{array}$ & $\begin{array}{l}\text { Gold production sold } \times \text { (gold price received }- \text { average } \\
\text { gold spot price), during period } t+1 \text {, in } \$ \text { Mill. }\end{array}$ & $\begin{array}{l}\text { Datastream, } \\
\text { annual report \& } \\
\text { form } 10-\mathrm{K}\end{array}$ \\
\hline $\begin{array}{l}\text { Hedging } \\
\text { dummy }\end{array}$ & $\begin{array}{l}\text { Variable equals one if a firm used derivatives during a } \\
\text { fiscal year and zero otherwise. }\end{array}$ & $\begin{array}{l}\text { Gold \& Silver } \\
\text { Hedge Survey } \\
(1989-1999)\end{array}$ \\
\hline $\begin{array}{l}\text { Extent of } \\
\text { hedging }\end{array}$ & $\begin{array}{l}\text { Fraction of future investment expenditures that have } \\
\text { been hedged. Variable equals the fixed future income } \\
\text { stream during period } t+1 \text { divided by actual investment } \\
\text { expenditures in period } t+1 \text {. }\end{array}$ & $\begin{array}{l}\text { Gold \& Silver } \\
\text { Hedge Survey } \\
(1989-1999) \\
\text { Compustat }\end{array}$ \\
\hline \multicolumn{3}{|c|}{ Cash flow variables (all variables are in $\$$ Mill and refer to period $t+1$ ) } \\
\hline $\begin{array}{l}\text { Investment } \\
\text { expenditures }\end{array}$ & Net investments in plant, property and equipment. & Compustat \\
\hline Net sales & Net sales excluding hedging cash flows. & Compustat \\
\hline $\begin{array}{l}\text { Operating net } \\
\text { cash flow }\end{array}$ & Operating net cash flow excluding hedging cash flows. & Compustat \\
\hline $\begin{array}{l}\text { Financing net } \\
\text { cash flow }\end{array}$ & $\begin{array}{l}\text { The net amount that has been raised from external capital } \\
\text { markets. }\end{array}$ & Compustat \\
\hline $\begin{array}{l}\text { Change in cash } \\
\text { position }\end{array}$ & Change in cash position excluding hedging cash flows. & Compustat \\
\hline \multicolumn{3}{|c|}{ Other control variables } \\
\hline $\begin{array}{l}\text { Net cash } \\
\text { holdings }\end{array}$ & $\begin{array}{l}\text { Cash and cash equivalents minus debt in current liabilit- } \\
\text { ies, in \$Mill. }\end{array}$ & Compustat \\
\hline \multicolumn{3}{|c|}{ Variables that proxy for the magnitude of financial constraints } \\
\hline Firm size & $\begin{array}{l}\text { Real market value of assets in } 1999 \text { dollars, calculated } \\
\text { using the producer price index for commodities. The } \\
\text { market value of assets equals the book value of assets } \\
\text { minus the book value of common stock plus the market } \\
\text { value of equity. }\end{array}$ & $\begin{array}{l}\text { Compustat, } \\
\text { Bureau of Labor } \\
\text { Statistics }\end{array}$ \\
\hline $\begin{array}{l}\text { Market-to-book } \\
\text { ratio of assets }\end{array}$ & $\begin{array}{l}\text { Market value of assets divided by book value of assets. } \\
\text { The Market value of assets equals the book value of as- } \\
\text { sets minus the book value of common stock plus market } \\
\text { value of equity. }\end{array}$ & Compustat \\
\hline
\end{tabular}


Table II. Continued

\begin{tabular}{|c|c|c|}
\hline Variable name & Construction & Data sources \\
\hline \multicolumn{3}{|c|}{ Variables that proxy for the magnitude of financial constraints (continued) } \\
\hline $\begin{array}{l}\text { Herfindahl } \\
\text { index } \\
\text { (based on asset } \\
\text { industry } \\
\text { segments) }\end{array}$ & $\begin{array}{l}\text { Defined by } \sum_{i=1}^{N}\left(\frac{q_{i}}{q}\right)^{2} \text {, where } q_{i} \text { is the book value of } \\
\text { assets of industry segment } i \text {, and } q \text { is the total book value } \\
\text { of all reported industry segment assets (non-reported as- } \\
\text { sets such as financial assets are ignored). } N \text { is the total } \\
\text { number of industry segments. }\end{array}$ & Compustat \\
\hline $\begin{array}{l}\text { Herfindahl } \\
\text { index } \\
\text { (based on metals } \\
\text { production) }\end{array}$ & $\begin{array}{l}\text { Defined by } \sum_{i=1}^{N}\left(\frac{s_{i}}{s}\right) \text {, where } s_{i} \text { is the revenue contribu- } \\
\text { tion of each metal (estimated as metal production } \times \text { spot } \\
\text { price), and } s \text { is the total metal sales for the year. } N \text { is } \\
\text { the total number of metals produced by the firm. If metal } \\
\text { production is zero, a missing value is assigned. }\end{array}$ & $\begin{array}{l}\text { Datastream, } \\
\text { annual report \& } \\
\text { form } 10-\mathrm{K}, \\
\text { Compustat }\end{array}$ \\
\hline Profit margin & $\begin{array}{l}\text { Difference between gold spot price and cash costs di- } \\
\text { vided by cash costs. Cash costs are the per-unit extraction } \\
\text { costs of gold. }\end{array}$ & $\begin{array}{l}\text { Datastream, } \\
\text { annual report \& } \\
\text { form } 10-\mathrm{K}\end{array}$ \\
\hline $\begin{array}{l}\text { Concentrated } \\
\text { ownership }\end{array}$ & $\begin{array}{l}\text { Total percentage of shares that are owned by corpor- } \\
\text { ations, which hold more than } 10 \% \text { of the outstanding } \\
\text { shares of the company. }\end{array}$ & $\begin{array}{l}\text { Proxy Statement } \\
\& \text { Management } \\
\text { Information } \\
\text { Circular }\end{array}$ \\
\hline $\begin{array}{l}\text { Cash dividend } \\
\text { dummy }\end{array}$ & $\begin{array}{l}\text { Dummy variable that equals one if a firm paid cash } \\
\text { dividends and zero otherwise. }\end{array}$ & Compustat \\
\hline $\begin{array}{l}\text { Credit rating } \\
\text { dummy }\end{array}$ & $\begin{array}{l}\text { Dummy variable that equals one if a credit rating exists } \\
\text { and zero otherwise. }\end{array}$ & Compustat \\
\hline Credit rating & $\begin{array}{l}\text { S\&P senior debt rating, ranging from } 2 \text { for a AAA rating } \\
\text { to } 24 \text { for a } \mathrm{C} \text { rating. A missing value is assigned if no } \\
\text { credit rating exists. }\end{array}$ & Compustat \\
\hline Leverage & $\begin{array}{l}\text { Book value of long-term debt plus book value of pre- } \\
\text { ferred stock divided by the book value of common equity. } \\
\text { If the book value of equity is negative, a missing value is } \\
\text { assigned. }\end{array}$ & Compustat \\
\hline Liquidity & $\begin{array}{l}\text { Liquidity is measured by a firm's quick ratio, which } \\
\text { is defined by (cash + cash equivalents + receivables) / } \\
\text { current liabilities. }\end{array}$ & Compustat \\
\hline $\begin{array}{l}\text { Aggressive } \\
\text { financial policy }\end{array}$ & $\begin{array}{l}\text { Dummy variable that equals one if a firm's leverage ratio } \\
\text { is above the industry median and its quick ratio below the } \\
\text { industry median. }\end{array}$ & Compustat \\
\hline $\begin{array}{l}\text { Conservative } \\
\text { financial policy }\end{array}$ & $\begin{array}{l}\text { Dummy variable that equals one if a firm's leverage ratio } \\
\text { is below the industry median and its quick ratio above the } \\
\text { industry median. }\end{array}$ & Compustat \\
\hline
\end{tabular}

All variables refer to time $t$ unless stated otherwise. 
of the contract. Theory predicts that this cash inflow is positively related to the firm's expected future investment expenditures. To minimize measurement error, I focus on investments that are scheduled for the next fiscal year and use actual investment expenditures as the best estimate of the expected investment expenditures. ${ }^{15}$ Consequently, I consider derivatives positions that mature within one year only when calculating a firm's fixed future income stream. ${ }^{16}$

Investments can be financed externally and/or internally. A firm's financing net cash flow represents the net amount of external capital raised during the fiscal year. Sources of internal financing are a firm's operating net cash flow, which is defined by net income plus any non-cash items (depreciation, amortization, etc.). A second measure of internal financing is the change in the cash position, which reflects the extent to which cash resources have been depleted to finance various expenditures. Both of these cash flow variables are affected by hedging. To eliminate the hedging effect, I calculate a firm's hedging net cash flow by (the average gold spot price during the fiscal year - the gold price received) $\times$ the gold sold, and subtract this amount from the operating net cash flow and the change in the cash position. I also use a firm's net cash position, defined by cash and cash equivalents minus debt due in one year, to proxy for a firm's ability to finance investments with retained cash.

There are several ways to measure the extent of hedging. Tufano (1996) measures the extent of hedging by a portfolio delta that represents the fraction of future gold production that has been hedged. Allayannis and Ofek (2001) define the extent of hedging by the notional principal of derivatives positions divided by the book value of assets. Graham and Rogers (2002) define the extent of hedging by the net notional principal and scale this variable by the book value of assets. According to Froot et al. (1993), firms should hedge their future investment expenditures. I therefore define the extent of hedging by the ratio of the fixed future income stream over investment expenditures.

Finally, for the analyses of the decision and the extent of hedging, I need variables that proxy for financial constraints. Most variables are standard and have been used before in numerous studies. These are firm size, diversification measures, the market-to-book ratio of assets, dividend policy, concentration of ownership, the existence of a credit rating and debt and liquidity ratios. Pulvino (1998) argues that it is uncertain if a highly levered but also highly liquid firm is financially constrained. Similarly, no unambiguous inference can be drawn for a firm with little debt but also low liquidity. Pulvino therefore suggests the use of a dummy variable that equals one if a firm's quick ratio is below and its leverage ratio is

\footnotetext{
15 Alternatively, one could use current investment expenditures to proxy for next year's expected investment expenditures. Investments, however, are lumpy. Hence, actual future expenditures probably provide the better estimate than past investment expenditures. Most econometric results still hold if current investment expenditures are used, although the statistical significance is lower.

16 A survey sent to the sample firms revealed that gold producers do not tend to roll over derivatives contracts or expect to close out positions early, but instead match the maturity of the derivative with the maturity of the exposure hedged. The response rate of the survey was $25.4 \%$.
} 
above the industry median and zero otherwise to identify financially constrained firms. A second dummy variable that equals one if a firm's quick ratio is above and its leverage ratio is below the industry median and zero otherwise identifies financially unconstrained firms. I also use these dummy variables in this study. However, I feel that the first variable more appropriately identifies firms that pursue an aggressive financial policy while the second variable identifies firms that pursue a conservative financial policy.

In addition to the standard proxy variables the available data allows me to calculate a firm's profit margins, which measures the probability of financial distress. This variable is defined by the difference between the spot price of gold and the cash production costs per ounce divided by the cash production costs. ${ }^{17}$ It measures the sensitivity of a firm's cash flows to changes in gold prices and is negatively related to the probability that a mine becomes unprofitable due to a decline in the gold price. Since the cash flow of a high-cost firm is more sensitive to downside shocks than the cash flow of a low-cost firm, a firm with a narrower profit margin faces a greater risk of financial distress.

\section{Results}

This section first describes some characteristics of firms in the gold mining industry and then analyzes the determinants of a firm's fixed future income stream and of a firm's external financing net cash flow. Finally, this section presents tests that show if financial constraints affect the decision to hedge and the extent of hedging.

\subsection{A DESCRIPTION OF FIRMS IN THE GOLD MINING INDUSTRY}

Table III provides descriptive statistics of firms in the North American gold mining industry. The gold mining industry is composed of mostly small firms and a few senior producers. The median firm has a market value of assets of only $\$ 217$ million, while only about $20 \%$ of firms have market values in excess of $\$ 1$ billion (the sample mean). Most firms concentrate on mining activities only, as indicated by the generally high values of the Herfindahl index based on firms' business segment assets. The also relatively high values of the Herfindahl index based on firms' metals production indicate that most firms produce only one metal: gold. Other metals, such as silver, copper and lead, are usually by-products of the gold production. Despite the focus on only one business segment, profit margins are low. The average price at which gold producers sold their gold between 1989 and 1999 was only $29 \%$ above cash costs. ${ }^{18}$ If one assumes the market-to-book ratio of assets to be a proxy for growth opportunities, then there appears to be a

\footnotetext{
17 Cash production costs include direct mining expenses, stripping and mine development costs, smelting, refining and transportation costs, and by-product credits.

18 See the previous footnote for a definition of cash costs. Cash costs exclude any non-cash items such as depreciation, amortization and depletion.
} 
Table III. Descriptive statistics of gold producers in North America. Variable definitions are given in Table II. The sample consists of 111 gold mining firms covering the years 1989-1999. There are a total of 595 firm-years

\begin{tabular}{lllllll}
\hline & Median & Mean & Std. dev & $10 \%$ & $90 \%$ & $N$ \\
\hline $\begin{array}{l}\text { Firm size } \\
\text { (in 1999 mill. dollars) }\end{array}$ & 216.7 & 991.8 & 1834.4 & 29.2 & 3038.4 & 536 \\
$\begin{array}{l}\text { Market-to-book ratio } \\
\text { of assets }\end{array}$ & 1.567 & 1.855 & 1.118 & 0.853 & 3.181 & 536 \\
Herfindahl index & 1 & 0.924 & 0.194 & 0.588 & 1 & 550 \\
(asset segments) & & & & & & \\
Herfindahl index & 1 & 0.867 & 0.209 & 0.511 & 1 & 503 \\
(metals production) & & & & & & \\
Profit margin & 0.293 & 0.283 & 0.213 & 0.039 & 0.516 & 481 \\
Concentrated ownership & 0 & 0.183 & 0.263 & 0 & 0.513 & 348 \\
Dividend dummy & 0 & 0.415 & 0.493 & 0 & 1 & 556 \\
Credit rating dummy & 0 & 0.172 & 0.378 & 0 & 1 & 592 \\
S\&P senior debt rating & $\mathrm{BB}+$ & $\mathrm{BB}+$ & & $\mathrm{BBB}+$ & $\mathrm{B}$ & 102 \\
Leverage & 0.155 & 0.226 & 0.257 & 0 & 0.522 & 545 \\
Liquidity & 1.680 & 3.438 & 6.087 & 0.247 & 6.699 & 553 \\
$\begin{array}{l}\text { Aggressive } \\
\text { financial policy }\end{array}$ & 0 & 0.316 & 0.465 & 0 & 1 & 548 \\
$\begin{array}{l}\text { Conservative } \\
\text { financial policy }\end{array}$ & 0 & 0.303 & 0.460 & 0 & 1 & 548 \\
Hedging dummy & 1 & 0.649 & 0.478 & 0 & 1 & 595 \\
\hline
\end{tabular}

significant dispersion in the growth opportunities across firms. The market-to-book ratio ranges from 0.29 to 9.08 in the sample. The ownership of most gold mining firms is also dispersed. The mean fraction of shares held by corporations is $18 \%$ while the median is 0 .

The small size of most firms, the relatively low profit margins and the focus on gold mining only are some reasons why debt capital is relatively expensive. Consequently, the average debt level in the mining industry is only $23 \%$ of assets and is thus comparatively low. Most of this debt is private. Only $17 \%$ of firms actually have a credit rating and, if one exists, it tends to be below investment grade. It is therefore not surprising that the majority of firms (59\%) do not pay cash dividends and maintain relatively high levels of liquid assets. The median quick ratio is 1.68 while the mean is 3.44 . Last, it is noteworthy that the majority of firms (65\%) use derivatives, but only $35 \%$ of firms that hedge with linear contracts use spot-deferred contracts. 
Table IV documents the differences between derivatives users and non-users with respect to the cash flow variables used in this study. Generally, firms that use derivatives are significantly larger than firms that do not use them. Their sales are about three times the sales of non-users. Operating net cash flows and investment expenditures are proportionally similar between hedgers and non-hedgers, i.e., these variables differ between hedgers and non-hedgers also by a factor of approximately three. However, firms that use derivatives appear to rely less on external and more on internal capital sources than firms that do not use derivatives. The financing net cash flow is proportionally low for hedgers, while their cash holdings as well as the change in cash holdings are proportionally large. More concretely, the median firm that does not hedge finances $100 \%$ of its investment expenditures externally, while the median firm that hedges finances only $86 \%$ of investments externally.

\subsection{DO FIRMS HEDGE THEIR FUTURE INVESTMENT EXPENDITURES?}

Hedging assures gold producers of a minimum revenue from their gold sales. As shown in Table IV, the average minimum revenue guaranteed by hedging (the fixed future income stream) is $\$ 84$ million, which constitutes about one-third of a firm's net sales. In this section I investigate if this fixed future income stream is related to a firm's investment expenditures.

Table $\mathrm{V}$ presents the results of regressions in which the fixed future income stream is regressed on investment expenditures and several control variables that measure the availability of internal and external financing sources. For example, a firm that anticipates accessing external capital markets requires less certainty about its revenue stream and thus needs to hedge less. The availability of external financing is measured by a firm's financing net cash flow, while the availability of internal financing is measured by net sales, the operating net cash flow, the change in the cash position, and the net cash holdings at the beginning of the period. Due to the high correlation between net sales and the operating net cash flow, these two regressors cannot be included in the same regression.

The first three columns in Table $\mathrm{V}$ show the results from the estimation of fixed-effects models on the pooled sample of derivatives users including all firmyears between 1989 and 1999. In all three regressions, a firm's future investment expenditures are an important determinant of the firm's fixed future income stream. None of the control variables is significantly different from zero except net sales. While some firms may also hedge their sales, this evidence is consistent with firms hedging their capital expenditures. Thus, through hedging, firms assure themselves of a fixed future income stream that covers some fraction of their future investment expenditures.

The previous analysis is based on the sample of derivatives users only. This approach would be warranted if the decision to use derivatives were random. However, previous research has shown that the decision to hedge is not random, which 
Table IV. Descriptive statistics of cash flow variables. This table contains descriptive statistics on firms' expenditures and financing sources for derivatives users and non-users. Table II contains descriptions of the variables. The ratio of the financing net cash flow over investment expenditures captures the maximum fraction of investment expenditures that are finance externally. This ratio is missing if the financing net cash flow is negative (a firm reduced the amount of external finance), and set equal to one if the amount of external finance raised is larger than the investment expenditures. The sample consists of 111 gold mining firms covering the years 1989-1999. There are a total of 595 firm-years. Medians, means, and percentiles are given in millions of US\$

\begin{tabular}{lrrrrrr}
\hline & Median & Mean & Std. dev & $10 \%$ & $90 \%$ & $N$ \\
\hline Panel A: Derivatives Users & & & & & & \\
Fixed future income stream & 24.1 & 83.7 & 188.6 & 1.8 & 205.0 & 386 \\
Hedging net cash flow & 0.8 & 10.1 & 35.4 & -0.6 & 23.0 & 386 \\
Net sales & 75.6 & 270.8 & 592.2 & 11.0 & 654.4 & 364 \\
Operating net cash flow & 10.2 & 46.7 & 94.1 & -3.5 & 134.9 & 361 \\
Investment expenditures & 23.4 & 69.3 & 108.1 & 3.8 & 210.5 & 363 \\
Financing net cash flow & 2.75 & 16.4 & 95.5 & -42.1 & 98.6 & 361 \\
Financing net cash flow/ & 0.86 & 0.68 & 0.36 & 0.09 & 1 & 178 \\
investment expenditures & & & & & & \\
Change in cash position & -2.0 & -8.4 & 63.4 & -62.6 & 44.9 & 363 \\
Net cash holdings & 12.1 & 50.7 & 112.2 & -9.8 & 181.9 & 362 \\
Panel B: Derivatives Non-Users & & & & & & \\
Net sales & 19.6 & 108.1 & 294.2 & 0.4 & 190.2 & 193 \\
Operating net cash flow & 1.9 & 21.7 & 76.8 & -4.2 & 49.5 & 192 \\
Investment expenditures & 6.8 & 30.7 & 83.5 & 0.7 & 61.6 & 192 \\
Financing net cash flow & 1.2 & 9.7 & 67.9 & -8.9 & 47.8 & 192 \\
Financing net cash flow/ & 1 & 0.71 & 0.38 & 0.06 & 1 & 113 \\
investment expenditures & & & & & & \\
Change in cash position & -0.3 & -0.4 & 43.8 & -15.6 & 33.3 & 192 \\
Net cash holdings & 6.0 & 29.1 & 67.5 & -3.8 & 118.8 & 193 \\
\hline
\end{tabular}

implies that the regression coefficients may be biased. To control for this selection bias I employ Heckman's selection model (see Heckman, 1976). Unfortunately, the maximum likelihood estimation does not converge when the full panel data set is used. I therefore calculate time-series averages from the firm-year observations of a single firm. If a company hedged for only some of the years during the sample period, I calculate two mean values: one based on those firm-years in which the company hedged and a second one based on those firm-years in which the company did not hedge. The estimation results are reported in the last three columns of Table V. A firm's investment expenditures appears again to be the most important determinant of a firm's fixed future income stream. A coefficient of about 0.6 implies that firms hedge $60 \%$ of their investment expenditures on average. 


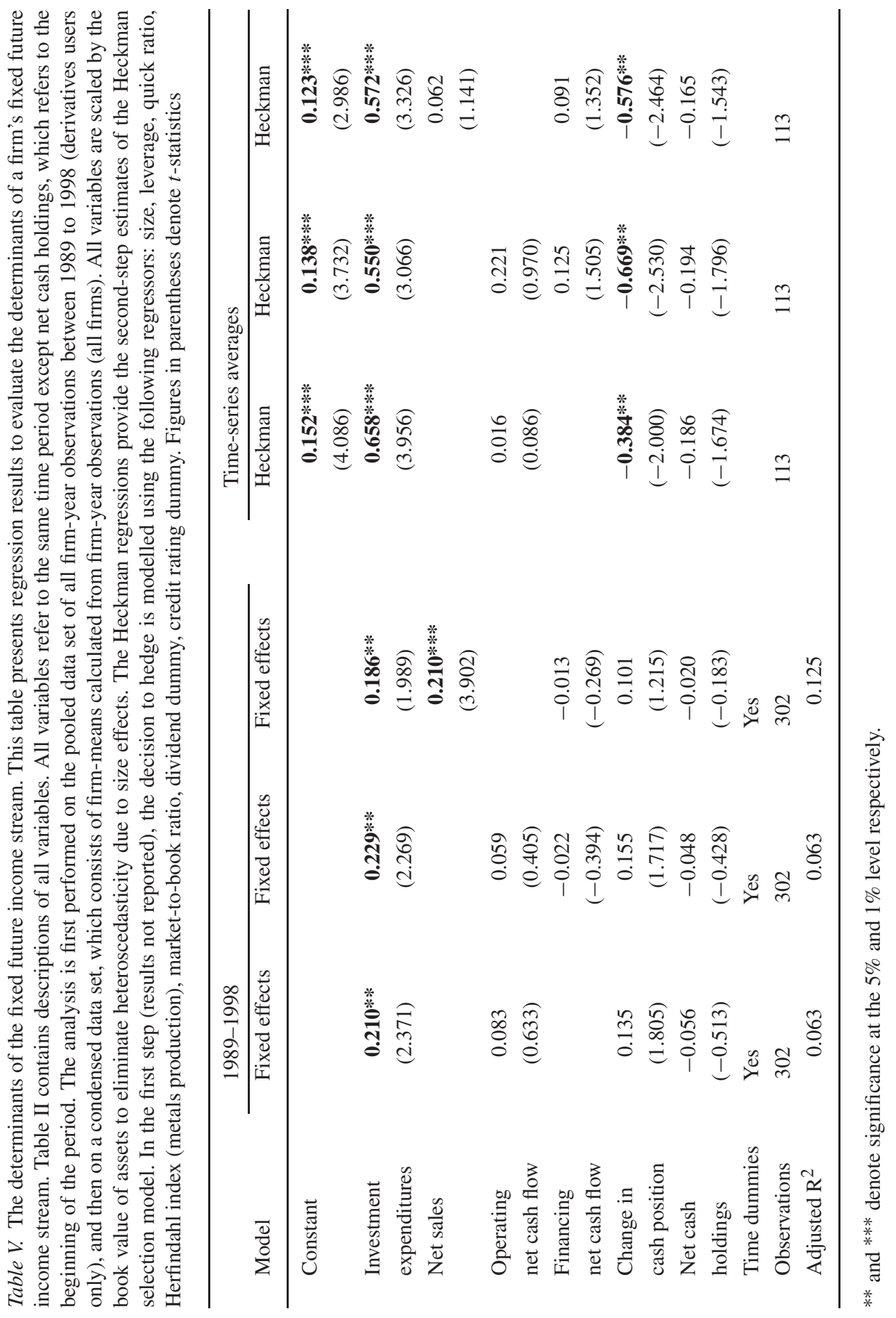


Table VI. Financing strategies (correlation coefficients). This table lists correlation coefficients between investment expenditures, and internal and external sources of financing for three subsamples: the full sample, the subsample of only derivatives users and the subsample of only derivatives non-users. The correlation coefficients in Panel A are based on level data, whereas the correlation coefficients in Panel B are based on changes. Variable definitions can be found in Table 2. The sample consists of 111 gold mining firms and covers the years 1989 to 1998. All variables refer to the same time period, and are scaled by the book value of assets to eliminate size effects. Correlation coefficients significantly different from zero at the $1 \%$ level appear in bold face.

\begin{tabular}{|c|c|c|c|c|}
\hline & & \multicolumn{3}{|c|}{ Investment expenditures } \\
\hline & & Full sample & Derivatives users & Derivatives non-users \\
\hline \multicolumn{5}{|c|}{ Panel A: Analysis of Levels } \\
\hline $\begin{array}{l}\text { External } \\
\text { financing }\end{array}$ & $\begin{array}{l}\text { Financing net cash } \\
\text { flow }\end{array}$ & 0.482 & 0.442 & 0.542 \\
\hline $\begin{array}{l}\text { Internal } \\
\text { financing }\end{array}$ & $\begin{array}{l}\text { Operating net cash } \\
\text { flow }\end{array}$ & 0.060 & 0.162 & -0.077 \\
\hline $\begin{array}{l}\text { Internal } \\
\text { financing }\end{array}$ & $\begin{array}{l}\text { Change in cash } \\
\text { position }\end{array}$ & 0.002 & -0.044 & 0.043 \\
\hline \multicolumn{5}{|c|}{ Panel B: Analysis of Changes } \\
\hline $\begin{array}{l}\text { External } \\
\text { financing }\end{array}$ & $\begin{array}{l}\text { Financing net cash } \\
\text { flow }\end{array}$ & 0.275 & 0.337 & 0.167 \\
\hline $\begin{array}{l}\text { Internal } \\
\text { financing }\end{array}$ & $\begin{array}{l}\text { Operating net cash } \\
\text { flow }\end{array}$ & 0.036 & 0.073 & -0.022 \\
\hline $\begin{array}{l}\text { Internal } \\
\text { financing }\end{array}$ & $\begin{array}{l}\text { Change in cash } \\
\text { position }\end{array}$ & 0.084 & 0.095 & 0.052 \\
\hline
\end{tabular}

\subsection{HOW FIRMS FINANCE THEIR INVESTMENT EXPENDITURES}

This section analyzes the determinants of a firm's financing net cash flow. In particular, I am concerned with the question of how firms typically finance their investment expenditures. Table VI presents correlation coefficients between firms' investment expenditures and internal and external financing sources. Irrespective of whether or not firms use derivatives, investment expenditures display the highest correlations with a firm's financing net cash flow (external financing). This result holds for levels and for changes. Thus, the correlation coefficients suggest that investments on average as well as the marginal investment project are financed externally rather than internally.

To test if a change in investment expenditures causes a change in the amount of external financing a firm raises, Table VII presents the results of regressions in which firms' financing net cash flows are regressed on firms' investment expenditures. The regressions are controlled for by other variables that measure the 
availability of internal funds and proxies for financial constraints. The analysis is conducted both on levels as well as on changes.

The coefficients on investment expenditures are statistically significant and economically large. They suggest a $1: 1$ relationship between investment expenditures and the amount of external financing raised. ${ }^{19}$ The sensitivity between investment expenditures and the financing net cash flow is lower for firms that hedge. However, the coefficient on the interaction term is statistically significant in only one of the four regressions in Table VII. The regression results further indicate that firms that have high operating net cash flows and maintain large cash balances raise less external financing. These results are confirmed if the regression is controlled by variables that proxy for financial constraints. Given the relatively high $\mathrm{R}^{2} \mathrm{~s}$ for a cross-section analysis, the data suggest that investment expenditures are an important determinant of how much external financing firms raise. Together with the previous finding, that firms' fixed future income stream is strongly positively related to future investment expenditures, this represents indirect evidence that firms hedge in order to reduce their dependence on external capital.

\subsection{DO FINANCIAL CONSTRAINTS AFFECT IF AND HOW MUCH FIRMS HEDGE?}

To provide a basis for comparison to previous studies in corporate risk management, I analyze the decision to hedge and the extent of hedging in this section. Since the determinants of the decision to hedge are likely to be different from the determinants of the extent of hedging I estimate a variant of the tobit model proposed by Cragg (1971). The estimation of this model is performed in two steps. In the first step, a standard probit model is estimated to analyze the determinants of the decision to hedge. The dependent variable takes on a value of one if a firm hedges and zero otherwise. In the second step, a truncated model is estimated on the subsample of derivatives users only to analyze the determinants of the extent of hedging. The extent of hedging is defined as the fixed future income stream over investment expenditures. This ratio represents the fraction of future investment expenditures that have been hedged.

The results are reported in Table VIII. Consistent with previous studies, I find that larger firms and firms that face greater exposure to gold prices (i.e., firms that primarily produce gold) are more likely to use derivatives than smaller firms and firms that produce a variety of metals. A further important determinant of the decision to hedge is the amount of liquidity a firm holds. Firms that hold more liquidity are less likely to hedge, which suggests that firms hold liquid assets as a substitute for hedging. Somewhat puzzling, I find a negative relation between the market-to-book ratio and the decision to hedge. The market-to-book ratio may proxy for several variables. Previous research has used this variable to measure growth opportunities as well as corporate performance. ${ }^{20}$ The negative coefficient

\footnotetext{
19 The coefficients are not statistically different from one.

20 See Adam and Goyal (2002) for a summary of this literature.
} 
Table VII. Why firms raise external financing? The dependent variable is firms' financing net cash flow. Variable definitions can be found in Table II. Figures in parentheses denote $t$-statistics and are adjusted for heteroscedasticity. All cash flow variables are scaled by the book value of assets to eliminate size effects. All regressions include time dummies.

\begin{tabular}{|c|c|c|c|c|}
\hline & \multicolumn{2}{|c|}{ Analysis of Levels } & \multicolumn{2}{|c|}{ Analysis of Changes } \\
\hline & Fixed effects & Fixed effects & Fixed effects & Fixed effects \\
\hline \multirow[t]{2}{*}{ Hedging dummy } & 0.080 & 0.059 & -0.009 & -0.004 \\
\hline & $(1.631)$ & $(1.072)$ & $(-0.242)$ & $(-0.113)$ \\
\hline \multirow[t]{2}{*}{ Investing expenditures } & $1.129 * * *$ & $0.961 * * *$ & $0.930 * * *$ & $0.555^{* *}$ \\
\hline & (7.141) & $(4.597)$ & (3.997) & $(2.235)$ \\
\hline Investing expenditures $\times$ & $-0.424 * *$ & -0.308 & -0.154 & -0.023 \\
\hline hedging dummy & $(-1.995)$ & $(-1.286)$ & $(-0.593)$ & $(-0.083)$ \\
\hline Operating & $-0.613 * * *$ & $-0.764 * * *$ & $-0.581 * * *$ & $-0.496 * * *$ \\
\hline net cash flow & $(-4.102)$ & $(-4.920)$ & $(-4.498)$ & $(-3.790)$ \\
\hline Hedging & 1.033 & 0.476 & 0.565 & 0.760 \\
\hline net cash flow & $(1.623)$ & $(0.718)$ & $(0.967)$ & $(1.345)$ \\
\hline \multirow[t]{2}{*}{ Net cash holdings } & $-0.258 * *$ & $-0.230 * *$ & $-0.562 * * *$ & $-0.523 * * *$ \\
\hline & $(-2.556)$ & $(-1.969)$ & $(-6.355)$ & $(-5.770)$ \\
\hline \multirow[t]{2}{*}{ Firm size } & & $-0.123 * * *$ & & $-0.241 * * *$ \\
\hline & & $(-3.135)$ & & $(-5.879)$ \\
\hline \multirow{2}{*}{ Market-to-book ratio } & & $0.084 * * *$ & & $0.057 * *$ \\
\hline & & $(3.867)$ & & $(2.565)$ \\
\hline Herfindahl index & & 0.096 & & 0.213 \\
\hline (asset segments) & & $(0.664)$ & & $(1.513)$ \\
\hline Herfindahl index & & 0.087 & & -0.153 \\
\hline (metals production) & & $(0.593)$ & & $(-1.049)$ \\
\hline \multirow[t]{2}{*}{ Profit margin } & & 0.126 & & 0.059 \\
\hline & & (1.318) & & $(0.510)$ \\
\hline \multirow[t]{2}{*}{ Rating dummy } & & -0.054 & & -0.029 \\
\hline & & $(-0.924)$ & & $(-0.504)$ \\
\hline \multirow[t]{2}{*}{ Dividend dummy } & & 0.023 & & 0.014 \\
\hline & & $(0.384)$ & & $(0.243)$ \\
\hline Aggressive & & $0.093 * *$ & & 0.056 \\
\hline financial policy & & $(2.296)$ & & (1.378) \\
\hline Conservative & & 0.038 & & 0.061 \\
\hline financial policy & & $(0.921)$ & & $(1.510)$ \\
\hline Observations & 441 & 374 & 407 & 352 \\
\hline Adjusted $\mathrm{R}^{2}$ & 0.326 & 0.382 & 0.293 & 0.401 \\
\hline
\end{tabular}

**, and $* * *$ denote significance at the $5 \%$, and $1 \%$ level respectively. 
would indicate that firms with fewer growth opportunities or below average performance are more likely to hedge. In the mining industry, the market-to-book ratio may also proxy for the maturity of a mining corporation. The primary activities in mining are exploration, development and production. A high market-to-book ratio may identify firms that are mostly involved in exploration and development and hence have a lot of growth options relative to their assets in place. A low marketto-book ratio may identify firms that are mostly involved in production and hence have fewer growth options relative to their assets in place. Since producers that are still in the exploration and development stages have no immediate transaction exposure to gold, they are less likely to hedge. Thus, if the market-to-book ratio captures the maturity of firms, then it would explain why more mature firms with relatively fewer growth options are more likely to hedge.

I do not find statistically significant relationships between the decision to hedge and other variables that may proxy for the existence or the magnitude of financial constraints, such as asset diversification across different business segments, profit margin, ownership structure, dividend policy, existence of a credit rating, leverage, and whether a firm pursues an aggressive or a conservative financial policy. Given that large firms are more likely than small firms to hedge, which is opposite to what a financial constraints argument would predict, I conclude that financial constraints are unlikely to drive the decision to hedge on average.

With respect to the extent of hedging, there is some evidence that the marketto-book ratio, the credit rating dummy, and the quick ratio are all negatively related to the extent of hedging. In addition, the Herfindahl index (asset segments) appears to be positively related to the extent of hedging. These results would support the conclusion that the magnitude of financial constraints does affect the extent of hedging. However, the respective coefficients are not statistically significant in all regressions. So, the empirical evidence is weak.

Even though I did not find convincing evidence that financial constraints affect the decision or the extent of hedging, I do not think this is sufficient to reject Froot et al. (1993) model. As argued previously, it is controversial if the proxy variables are successful in measuring financial constraints. In addition, the extent of hedging has no clear theoretical relation to the magnitude of financial constraints. Furthermore, it is possible that some firms decide not to hedge, not because they are less financially constrained but because other concerns are more important to them, e.g., shareholders' preferences towards hedging. ${ }^{21}$ In such a case, I would not expect to find a significant relation between financial constraints and the decision to hedge. In contrast, Froot et al. (1993) model is, to my knowledge, the only model that links hedging activities to investment expenditures. The empirical results confirm this link and thus imply that Froot, Scharfstein and Stein's model describes actual hedging behavior.

\footnotetext{
21 For example, until 1997 Homestake Mining deliberately chose not to hedge because management argued that shareholders invested in Homestake because of the gold exposure.
} 


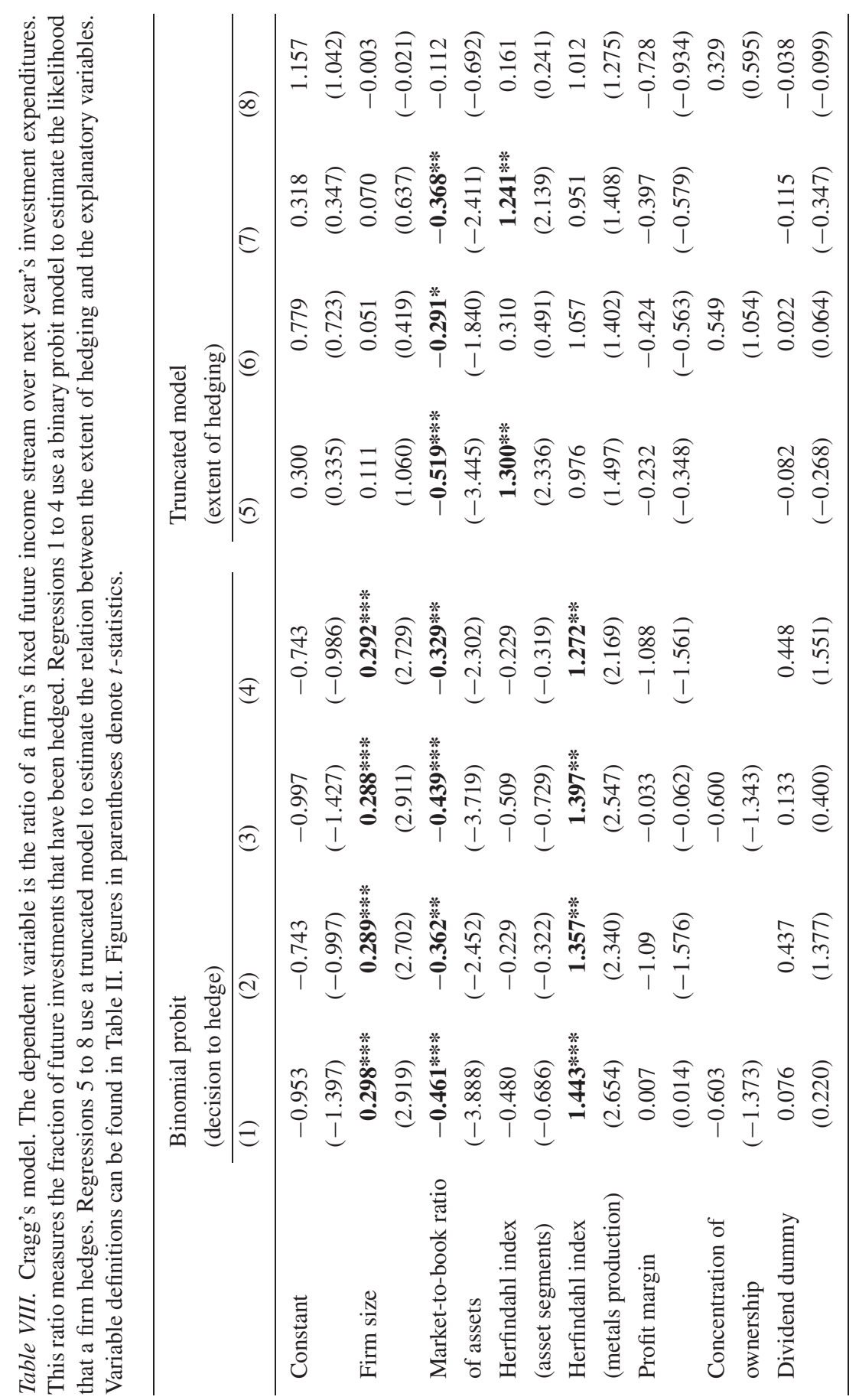




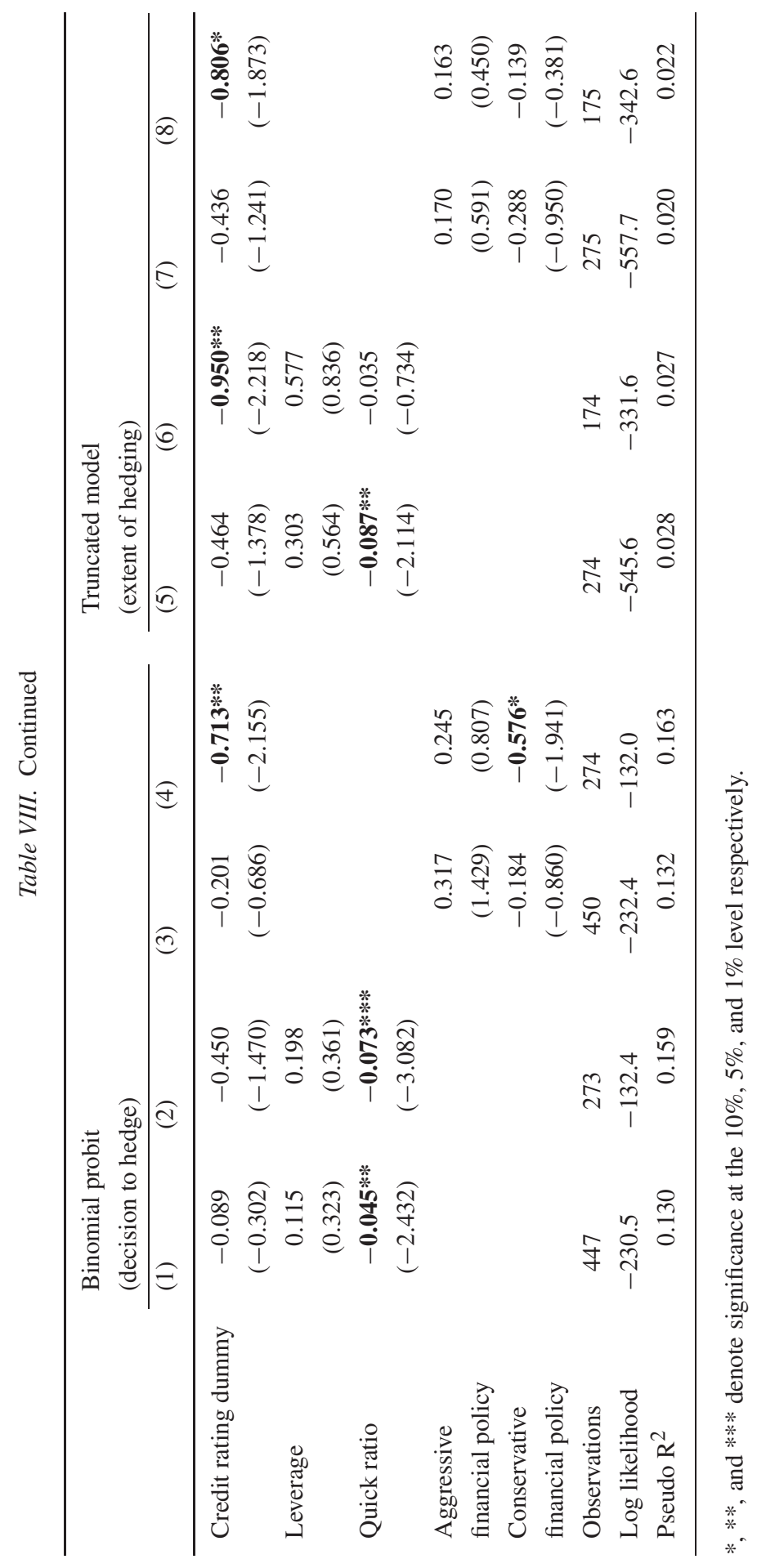




\section{Conclusion}

This paper provides empirical evidence that is consistent with the hypothesis that firms hedge their future investment expenditures. Since investment expenditures are typically financed externally, but hedging cash flows are a form of internal financing, this finding implies that firms hedge to reduce their dependence on external capital markets. Consistent with this result, I find that firms that do hedge finance a smaller fraction of their investment expenditures externally than do firms that do not hedge. This result is significant not only because it gives credibility to Froot et al. (1993) theory of corporate risk management, but also because it suggests that a well-developed derivatives market can overcome some of the constraints imposed by a less-developed capital market.

\section{References}

Adam, T., and Goyal, V. (2002) The investment opportunity set and its proxy variables: Theory and ervidence, Working Paper, Hong Kong University of Science \& Technology.

Allayannis, G. and Ofek, E. (2001) Exchange rate exposure, hedging, and the use of foreign currency derivatives, Journal of International Money and Finance 20, 273-296.

Allayannis, G. and Mozumdar, A. (2000) Cash flow, investment, and hedging, Working Paper, University of Virginia.

Brown, G. W., Crabb, P. R., and Haushalter, D. (2001) Are firms successful at 'selective' hedging?, Working Paper, University of North Carolina.

Cragg, J. (1971) Some statistical models for limited dependent variables with application to the demand for durable goods, Econometrica 39, 829-844.

Dolde, W. (1996) Hedging, leverage, and primitive risk, Journal of Financial Engineering 4, 187216.

Fazzari, S., Hubbard, R. G., and Petersen, B. (1988) Financing constraints and corporate investment, Brookings Papers on Economic Activity, 141-195.

Froot, K. A., Scharfstein, D. S., and Stein, J. C. (1993) Risk management: Coordinating corporate investment and financing policies, Journal of Finance 48, 1629-1658.

Géczy, C., Minton, B. A., and Schrand, C. (1997) Why firms use currency derivatives, Journal of Finance 52, 132-154.

Graham, J. R. and Rogers, D. A. (2002) Do firms hedge in response to tax incentives? Journal of Finance forthcoming.

Haushalter, G. D. (2000) Financing policy, basis risk, and corporate hedging: Evidence from oil and gas producers, Journal of Finance 55, 107-152.

Heckman, J. (1976) The common structure of statistical models of truncation, sample selection, and limited dependent variables and a simple estimator for such models, The Annals of Economic and Social Measurement 5, 475-492.

Kaplan, S. N. and Zingales, L. (2000) Investment-cash flow sensitivities are not valid measures of financing constraints, Quarterly Journal of Economics 115, 707-1012.

Kaplan, S. N. and Zingales, L. (1997) Do investment-cash flow sensitivities provide useful measures of financing constraints? Quarterly Journal of Economics 112, 169-215.

Mian, S. L. (1996) Evidence on corporate hedging policy, Journal of Financial and Quantitative Analysis 31, 419-439.

Minton, B. A. and Schrand, C. (1999) The impact of cash flow volatility on discretionary investment and the costs of debt and equity financing, Journal of Financial Economics 54, 423-460. 
Myers, S. and Majluf, N. (1984) Corporate financing and investment decisions when firms have information that investors do not have, Journal of Financial Economics 13, 187-221.

Nance, D. R., Smith C. W., and Smithson, C. W. (1993) On the determinants of corporate hedging, Journal of Finance 48, 267-284.

Petersen, M. A. and Thiagarajan, S. R. (2000) Risk measurement and hedging: With and without derivatives, Financial Management 29, 5-29.

Pulvino, T. C. (1998) Do asset fire-sales exist? An empirical investigation of commercial aircraft transactions, Journal of Finance 53, 939-978.

Tufano, P. (1996) Who manages risk? An empirical examination of risk management practices in the gold mining industry, Journal of Finance 51, 1097-1137.

Tufano, P. (1998) The determinants of stock price exposure: Financial engineering and the gold mining industry, Journal of Finance 53, 1051-1052. 
